\title{
KAJIAN PENGEMBANGAN SUMBERDAYA MANUSIA PETANI DALAM PEMBUATAN PUPUK ORGANIK DI DESA BICORONG KECAMATAN PAKONG KABUPATEN PAMEKASAN
}

\section{Disusun Oleh : Kustiawati Ningsih}

ABSTRAK:Pembangunan pertanian merupakan proses peningkatan produktivitas sistem pertanian yang dilakukan oleh berbagai pihak seperti pemerintah dan pemangku kepentingan dengan cara memanfaatkan beragam sumber daya alam, ilmu pengetahuan dan teknologi, modal, sumber daya manusia dan kelembagaan yang ditujukan untuk meningkatkan kesejahteraan keluarga dan masyarakat pertanian. Dengan pembangunan pertanian diharapkan mampu mensukseskan Gerakan Go Organik yang telah dicanangkan oleh Pemerintah.

Revolusi hijau menimbulkan dampak negatif yang nyata terhadap lingkungan. Hasil analisa tanah yang dilakukan oleh Dinas Pertanian Kabupaten Pamekasan diperoleh bahwa kandungan unsure hara alami di dalam tanah hanya berkisar 1-2\%. Jauh dari kebutuhan minimal dimana tanah harus mempunyai kandungan unsur hara minimal $5 \%$. Berdasarkan observasi yang dilakukan peneliti, terdapat beberapa permasalahan yang ditemukan di Desa Bicorong Kecamatan Pakong Kabupaten Pamekasan adalah faktor-faktor apa saja yang mempengaruhi pengembangan SDM petani dalam pembuatan pupuk organik di Desa Bicorong? Serta bagaimana alternatif strategi pengembangan SDM petani dalam pembuatan pupuk organik di Desa Bicorong?

Hasil penelitian menunjukkan bahwa faktor intenal yaitu faktor kekuatan mempunyai nilai total sebesar 82,35 \% terdiri dari faktor kelompok tani sebesar 95,33 \%; tersedianya hewan ternak 83\%; irigasi semi teknis 93,33\%; motivasi berkelompok 83,60 \%; ketersediaan lahan yang masih luas $80 \%$; kebijakan pemerintah yang mendukung 76,67 \%; tenaga kerja cukup tersedia 64,33 \%. Faktor kelemahan mempunyai nilai total sebesar 76,81 \% terdiri dari faktor penerapan teknologi yang masih rendah sebesar 93,67 \%; modal usaha tani kurang 87,67 \%; produksi dan kualitas masih rendah 83,67 \%; umur petani relatif tua $75 \%$; penggunaan dosis pupuk berlebihan $73 \%$; pendidikan masih rendah 70,33\%; pemberdayaan kelompok tani masih kurang sebesar 50\%; lahan usaha tani sempit $53,33 \%$.

Faktor eksternal menunjukkan bahwa faktor peluang mempunyai nilai total sebesar $87,53 \%$ terdiri dari faktor kebijakan pemerintah yang mendukung sebesar $100 \%$; diversifikasi pangan $93 \%$; teknologi masih bisa dikembangkan 89,67 \%; pemanfaatan lahan kering 91,67 \%; pertumbuhan penduduk 70,33\%. Faktor ancaman mempunyai nilai total sebesar 69,8 \% terdiri dari faktor biaya produksi semakin meningkat 89,67\%; serangan hama dan penyakit 87,33\%; 
irigasi belum lancar $81 \%$; distribusi pupuk kurang lancar $81 \%$; perubahan cuaca dan bencana alam $73 \%$.

Disimpulkan bahwa strategi pengembangan SDM petani di Desa Bicorong adalah strategi kekuatan - peluang (S-O) yaitu meningkatkan pembinaan petani melalui kelompok tani yang dilakukan secara intensif dan berkesinambungan, optimalisasi lahan pertanian dan sumber air melalui konsep agribisnis dan berkelanjutan serta optimalisasi pemanfaatan kotoran hewan ternak sebagai pupuk organik.

\section{Kata kunci : sumberdaya manusia, pupuk organik}

\section{PENDAHULUAN}

Revolusi hijau diterapkan diseluruh Indonesia terlebih pada daerah-daerah yang dikenal sebagai sentra produksi pangan. Pemerintah memperkenalkan kepada petani teknologi revolusi hijau dengan suatu asumsi bahwa teknologi tersebut akan meningkatkan produksi, dan dengan peningkatan produksi yang dicapai akan meningkatkan kesejahteraan dan kemakmuran petani. Akhir tahun 1969 dengan adanya BIMAS dan INMAS sebagai pelaksana Revolusi Hijau, situasi pertanian dan pedesaan awalnya seolah nampak subur makmur, namun dalam jangka panjangnya ternyata sangat mengecewakan. Kaum tani semakin tergantung pada pupuk buatan (Urea dan sejenisnya), pestisida kimia, dan lain-lain.

Kritik terhadap revolusi hijau adalah terlalu tergantung pada input tinggi, khususnya pupuk kimia dan insektisida kimia. Salah satu paket pertanian modern memiliki dampak yang bersifat toksik bagi organisme lain dan mengganggu ekologi tanaman. Kondisi yang demikian juga terjadi di Kabupaten Pamekasan. Seiring dengan berjalannya waktu akibat dari pemakaian pupuk dan pestisida kimia secara terus menerus menyebabkan kesuburan tanah berkurang dan terjadinya kerusakan lingkungan. Hasil analisa tanah yang dilakukan oleh Dinas Pertanian Kabupaten Pamekasan diperoleh bahwa kandungan unsure hara alami di dalam tanah hanya berkisar 1-2\%. Jauh dari kebutuhan minimal dimana tanah harus mempunyai kandungan unsur hara minimal $5 \%$. Revolusi hijau dengan asumsi yang mendasarkan pada pertumbuhan itu ternyata salah. Pertumbuhan produksi yang berhasil dicapai tidak mampu mengangkat kesejahteraan petani. Revolusi hijau justru meminggirkan petani. Petani menjadi tergantung pada perusahaan-perusahaan besar untuk menjalankan usaha pertanian mereka. Selain memarjinalkan petani revolusi hijau juga membawa 
dampak kerusakan yang luas terhadap lingkungan. Tanah persawahan semakin lama menjadi semakin keras dan bantat. Penggunaan pupuk kimia meningkat dari waktu kewaktu.

Seiring dengan

meningkatnya kesadaran masyarakat akan pentingnya mengembangkan sistem pertanian yang berwawasan lingkungan dan berkelanjutan, pertanian organik menjadi salah satu pilihan yang dapat diambil misalnya dengan pembuatan pupuk organik. Pemerintah akhirnya mempunyai komitmen untuk mengembangkan pertanian organik yang pada awal revolusi hijau tidak mendapat perhatian yang memadai. Departemen Pertanian mencanangkan Program Go Organik 2010 dengan berbagai pentahapannya yang dimulai pada tahun 2001. Dilain pihak SDM petani sangat tidak mendukung terhadap Program Go Organik khususnya pada pembuatan pupuk organik.

Pembangunan pertanian merupakan proses peningkatan produktivitas sistem pertanian yang dilakukan oleh berbagai pihak seperti pemerintah dan pemangku kepentingan dengan cara memanfaatkan beragam sumber daya alam, ilmu pengetahuan dan teknologi, modal, sumber daya manusia dan kelembagaan yang ditujukan untuk meningkatkan kesejahteraan keluarga dan masyarakat pertanian. Dengan pembangunan pertanian diharapkan mampu mensukseskan Gerakan Go Organik yang telah dicanangkan oleh Pemerintah.

Pembangunan pertanian selalu diindentikkan dengan kegiatan produksi usahatani dan kurang memberi kesempatan untuk pengembangan produksi hilir sehingga dalam 10 tahun terakhir, peningkatan produktivitas usahatani di tingkat petani relatif stagnan dan kapasitas produksi pertanian secara nasional semakin terbatas. Hal ini disebabkan peningkatan kualitas dan mentalitas sumber daya manusia pertanian berjalan lambat (Deptan, 2007).

Dimasa mendatang sektor pertanian akan menghadapi era globalisasi yang memerlukan antisipasi secara tepat. Pada era tersebut Indonesia tidak hanya memproduksi produk pertanian tetapi juga menjadi pasar dari produk pertanian negara lain. Keberhasilan proses pembangunan pertanian pada era globalisasi tergantung pada penguasaan teknologi pertanian dan kemampuan bersaing dari para petani suatu negara (Anantanyu, 2004).

Sejak berdirinya Departemen Pertanian (Van Landbouw) pada tahun 1905, menjadi awal bagi pemberdayaan petani di Indonesia dengan program penyuluhan. Pendekatan penyuluhan pertanian yang selama ini diterapkan adalah pendekatan kelompok tani, karena kelompok-kelompok masyarakat 
dapat menjadi wahana belajar dan kemajuan yang bergerak secara mandiri. Hal ini sesuai dengan Peraturan Menteri Pertanian No.273/kpts/OT.160/4/2007 bahwa peningkatan kualitas Sumber Daya Manusia sebagai pelaku utama pembangunan pertanian diupayakan melalui penyuluhan pertanian dengan pendekatan kelompok yang dapat mendukung sistem agribisnis.

Kelompok tani "Sumber Besar" adalah salah satu kelompok tani yang ada di Desa Bicorong. Potensi sumber daya alam di Desa Bicorong masih banyak namun tingkat kesejahteraan masyarakat yang mayoritas penduduknya adalah petani masih rendah. Hal ini disebabkan masalah yang ada, diantaranya: rendahnya pengetahuan dan wawasan; rendahnya teknologi yang digunakan; terbatasnya modal dan sarana produksi usaha tani dan kelembagaan belum mendukung.

Pemberdayaan seharusnya mampu membawa perubahan petani agar mencapai taraf hidup yang sejahtera. Oleh karena itu diperlukan langkah-langkah strategis untuk meningkatkan SDM petani dalam pembuatan pupuk organik di Desa Bicorong.

Berdasarkan uraian latar belakang di atas, maka dapat dirumuskan pertanyaan pokok dalam penelitian ini sebagai berikut:

1. Apa saja faktor-faktor yang mempengaruhi pengembangan SDM petani dalam pembuatan pupuk organik di Desa Bicorong?

2. Bagaimana alternatif strategi pengembangan SDM petani dalam pembuatan pupuk organik di Desa Bicorong?

\section{TUJUAN PENELITIAN}

1. Untuk mengetahui faktor internal dan faktor eksternal yang mempengaruhi pengembangan SDM petani dalam pembuatan pupuk organik di Desa Bicorong.

2. Untuk mengetahui alternatif strategi pengembangan SDM petani dalam pembuatan pupuk organik di Desa Bicorong.

\section{METODE PENELITIAN}

\section{A. Tempat dan Waktu Penelitian}

Penelitian ini dilaksanakan di Kelompok Tani Sumber Raya Desa Bicorong, Kecamatan Pakong, Kabupaten Pemekasan yang ditentukan secara sengaja (purposive) dengan pertimbangan bahwa sebagian besar petani di Desa Bicorong tergabung dalam kelompok tani.

\section{B. Metode Penentuan Sampel}

Metode pengambilan sampel yang digunakan adalah metode survei. Survei adalah pengamatan atau penyelidikan yang kritis untuk mendapatkan keterangan yang baik terhadap suatu persoalan tertentu didalam daerah atau lokasi tertentu, atau suatu studi ekstensif yang 
diperlukan untuk memperoleh informasi-informasi yang dibutuhkan (Daniel, 2003). Tujuan dari survei adalah mendapatkan gambaran yang mewakili daerah itu dengan benar. Sampel penelitian adalah kelompok tani "Sumber Besar" di Desa Bicorong. Adapun responden yang dijadikan sasaran penelitian adalah anggota kelompok tani Sumber Besar dengan jumlah 30 orang.

\section{Metode Pengumpulan Data}

Data diperoleh dengan cara pengumpulan data primer dan data sekunder.

1. Pengumpulan Data Primer

Data primer diperoleh dengan cara melakukan wawancara langsung dengan responden yang ditunjang dengan pengisian kuisioner. Jenis data yang diambil adalah tingkat penerapan teknologi budidaya tanaman; tingkat penggunaan pupuk berimbang; faktor-faktor internal dan faktorfaktor eksternal.

2. Pengumpulan Data Sekunder

Data sekunder diperoleh dari instansi terkait seperti Sekretariat Kelompok Tani "Sumber Raya", Balai Desa Bicorong, BPP Pakong dan Dinas Pertanian Kabupaten Pamekasan. Jenis data yang diambil adalah data penduduk Desa Bicorong; produksi petani Desa Bicorong; stuktur kepengurusan Kelompok Tani Sumber Raya.

\section{Metode Analisa Data}

Analisa SWOT digunakan untuk menentukan strategi pengembangan SDM petani dalam pembuatan pupuk organik. Analisa SWOT adalah identifikasi berbagai faktor secara sistematis untuk merumuskan strategi yang paling cocok (Rangkuti, 2001). SWOT terdiri dari kekuatan (Strengths) dan kelemahan (Weaknesses) merupakan faktor internal serta peluang (Opportunities) dan ancaman (Threats) merupakan faktor eksternal. Analisa SWOT membandingkan antara faktor internal dan eksternal dengan asumsi bahwa suatu strategi yang efektif akan memaksimalkan kekuatan dan peluang serta meminimalkan kelemahan dan ancaman.

Kekuatan adalah sumberdaya dan keterampilan yang memberikan keunggulan bagi perusahaan. Kelemahan adalah keterbatasan atau kekurangan dalam sumberdaya dan keterampilan yang secara serius menghambat kinerja perusahaan. Peluang adalah situasi penting yang menguntungkan dalam lingkungan perusahaan. Ancaman adalah situasi penting yang tidak menguntungkan dalam lingkungan perusahaan.

Indikator faktor internal yang mempengaruhi pengembangan SDM petani mencakup berbagai variabel yang terkait dengan aspek: kelembagaan, produksi, sumberdaya 
fisik dan sumber daya finansial. Sedangkan indikator faktor eksternal terdiri dari variabel yang terkait dengan aspek: kebijakan pemerintah, kondisi pasar input/output, kondisi sosial masyarakat, kondisi perekonomian, perkembangan sektor swasta, kondisi politik dan keamanan, serta hama/penyakit dan perubahan cuaca.

Untuk menentukan faktorfaktor yang mempengaruhi pengembangan SDM petani dilakukan dengan mengidentifikasi faktor-faktor yang menjadi kekuatan dan kelemahan dari aspek internal serta faktor-faktor yang menjadi peluang dan ancaman dari aspek eksternal.

Matrik SWOT digunakan untuk menghasilkan empat set alternatif strategi pengembangan SDM petani, seperti ditunjukkan pada gambar berikut.

\begin{tabular}{|c|c|c|}
\hline $\begin{array}{l}\text { Faktor Internal } \\
\text { Faktor Eksternal }\end{array}$ & $\begin{array}{l}\text { STRENGTHS (S) } \\
\text { Tentukan 5-10 } \\
\text { faktor kekuatan } \\
\text { internal }\end{array}$ & $\begin{array}{l}\text { WEAKNESSES (W) } \\
\text { - } \quad \text { Tentukan 5-10 faktor } \\
\text { kelemahan internal }\end{array}$ \\
\hline $\begin{array}{l}\text { OPPORTUNITIES (O) } \\
\text { - } \begin{array}{l}\text { Tentukan 5-10 faktor } \\
\text { peluang eksternal }\end{array}\end{array}$ & \begin{tabular}{l}
\multicolumn{1}{c}{ STRATEGI SO } \\
Ciptakan strategi yang \\
menggunakan kekuatan \\
untuk memanfaatkan \\
peluang
\end{tabular} & \begin{tabular}{l}
\multicolumn{1}{c}{ STRATEGI WO } \\
Ciptakan strategi yang \\
meminimalkan \\
kelemahan untuk \\
memanfaatkan peluang
\end{tabular} \\
\hline $\begin{array}{l}\text { THREATS (T) } \\
\text { - Tentukan 5-10 faktor } \\
\text { ancaman eksternal }\end{array}$ & $\begin{array}{l}\quad \text { STRATEGI ST } \\
\text { Ciptakan strategi yang } \\
\text { menggunakan kekuatan } \\
\text { untuk mengatasi } \\
\text { ancaman }\end{array}$ & \begin{tabular}{l}
\multicolumn{1}{c}{ STRATEGI WT } \\
Ciptakan strategi yang \\
meminimalkan \\
kelemahan dan \\
menghindari ancaman
\end{tabular} \\
\hline
\end{tabular}

Sumber: Freddy Rangkuti (2001)

Prioritas strategi dilakukan dengan menilai faktor-faktor internal dan faktor-faktor eksternal berdasarkan tingkat kepentingan. Penilaian pendapat menggunakan skala likert kemudian data tingkat kepentingan di analisis menggunakan skala nilai (rating scale) yaitu data mentah yang berupa angka kemudian ditafsirkan secara kualitatif menggunakan rumus :

Total nilai yang digunakan dalam evaluasi Total

Nitai X $100 \%$

Nilai

maksimum yang dicapai

Alternatif jawaban yang digunakan: 
Sangat penting $\quad: 5$

Penting : 4

Cukup penting : 3

Kurang penting $: 2$

Tidak penting

$: 1$

\section{HASIL PENELITIAN DAN PEMBAHASAN}

\section{A. Faktor - faktor yang Mempengaruhi \\ Pengembangan SDM Petani dalam Pembuatan Pupuk Organik di Desa Bicorong}

Hasil identifikasi kekuatan

$(\mathrm{S})$, kelemahan $(\mathrm{W})$, peluang $(\mathrm{O})$ dan tantangan ( $\mathrm{T}$ ) dalam pengembangan SDM petani di Desa Bicorong sebagai berikut:

\section{Faktor-faktor Internal}

Faktor-faktor internal adalah faktor-faktor yang berasal dari dalam lingkungan petani sendiri terdiri dari kekuatan (S) dan kelemahan (W).

\section{a. Kekuatan (S)}

1. Tersedianya hewan ternak

Berdasarkan data monograf Desa Bicorong tahun 2010, jumlah ternak yang terdapat di Desa Bicorong sejumlah 1824 ekor yang terdiri dari sapi, kambing dan unggas. Dengan demikian, maka bahan baku untuk pembuatan pupuk organik yaitu kotoran hewan ternak, dapat terpenuhi.

2. Ada kelompok tani

Kelompok tani adalah kelembagaan petani yang ada di desa. Dari data monografi Desa Bicorong tahun 2010, tercatat ada tiga kelompok tani yang berada di tiap dusun.

3. Ada motivasi untuk berkelompok

Kekuatan internal yang menyebabkan seseorang melakukan suatu tindakan untuk mencapai tujuannya adalah motivasi. Adanya partisipasi petani untuk berkelompok akan mempercepat perubahan perilaku dan meningkatkan kemampuan petani dalam mengelola sumberdaya. Dari data monografi Desa Bicorong tahun 2010, tercatat 97 anggota aktif yang tergabung pada tiga kelompok tani yang ada.

4. Kebijakan pemerintah mendukung

Penyuluhan pertanian dapat membantu petani dalam transfer informasi dan teknologi pertanian. Program satu penyuluh pertanian dalam satu desa diharapkan mampu membantu petani untuk meningkatkan keberdayaannya.

5. Tenaga kerja cukup tersedia

Berdasarkan data monografi Desa Bicorong tahun 2010, mata pencaharian sebagai petani berjumlah 1701 orang dan buruh tani sebanyak 189 orang, dari jumlah tersebut tenaga kerja pertanian masih dapat terpenuhi dari Desa Bicorong sendiri.

6. Ketersediaan lahan masih luas

Lahan pertanian di Desa Bicorong merupakan lahan kering, penggunaan lahan tersebut terdiri dari sawah irigasi semi teknis (179 Ha), sawah tadah hujan (28,54 Ha), lahan kering (234 Ha). Sebagian 
besar lahan ditanami padi, jagung, tembakau, dan ketela pohon.

7. Ada irigasi semi teknis

Di Desa Bicorong terdapat dua unit sumur bor yang mampu mengairi 70 Ha sawah. Adanya irigasi dapat mendukung petani untuk mengembangkan usaha pertanian dengan konsep agribisnis.

\section{b. Kelemahan (W)}

1. Penerapan teknologi masih rendah

Pengembangan usahatani memerlukan informasi dan teknologi pertanian. Faktor-faktor yang mempengaruhi pertumbuhan tanaman meliputi penggunaan varietas unggul, pengolahan lahan, jarak tanam dan larikan serta penggunaan pupuk organik.

Berdasarkan

hasil

wawancara petani responden

menunjukkan petani telah melakukan tahapan budidaya tanaman namun tingkat penerapan teknologinya masih bervariasi. Berdasarkan hasil wawancara, petani responden belum semuanya menggunakan varietas unggul presentasenya masih mencapai 93,33 $\%$, pengolahan tanah yang merupakan kegiatan awal untuk mempersiapkan tanah sebagai media tumbuh tanaman padi masih 76, 67 $\%$, petani belum menggunakan larikan yang bertujuan mempermudah pemeliharaan sedangkan penggunaan pupuk organik masih $60 \%$.
Status kepemilikan lahan merupakan faktor yang juga mempengaruhi penerapan teknologi budidaya tanaman. Kepemilikan lahan memberikan keleluasaan untuk melakukan penerapan teknologi dibandingkan dengan status sebagai penyewa dan bagi hasil yang terdiri dari $23,33 \%$ petani responden status kepemilikan lahannya adalah lahan sewa dan bagi hasil.

2. Modal usaha tani kurang

Keterbatasan modal usaha tani dan kepemilikan lahan akan berpengaruh terhadap penyediaan sarana produksi dan pengembangan usaha tani.

3. Lahan usaha tani sempit

Luas lahan garapan dapat memberikan pengaruh terhadap tingkat pendapatan dan penerapan teknologi, semakin luas lahan garapan semakin mampu memberikan jaminan hidup sebagai sumber pendapatan keluarga.

Berdasarkan

hasil

wawancara dengan petani responden menunjukkan petani responden yang memiliki luas lahan garapan 0,10 0,50 Ha sebesar 66,67 \%. Hal ini menunjukkan bahwa luas lahan garapan yang dikelola oleh petani sangat sempit. Hasil tersebut hanya mampu memenuhi kebutuhan pangan keluarga sehingga teknologi budidaya tidak lagi diperhatikan karena terbatasnya dana untuk sarana produksi.

4. Produksi dan kualitas masih rendah 
Dari data monografi Desa Bicorong tahun 2010, diketahui bahwa produksi rata-rata petani Bicorong sebesar 6,4 ton/Ha dan kualitas yang dihasilkan masih rendah. Hal ini terjadi karena petani belum melakukan pemupukan berimbang.

Hasil wawancara dengan petani responden memperlihatkan bahwa tingkat penggunaan pupuk Urea mencapai presentase tertinggi yaitu $100 \%$ karena respon pupuk Urea terhadap tanaman dapat terlihat lebih cepat terhadap pertumbuhan tanaman dan warna daun. Penggunaan pupuk Ponska setiap musim tanam hanya $30 \%$ dan sebesar $70 \%$ tidak menggunakan. Demikian juga penggunaan ZA, petani responden yang menggunakan hanya 36,67 \% sedangkan yang tidak menggunakan sebesar 63,33 \%. Penggunaan pupuk kandang oleh petani responden sebesar $70 \%$ dan $30 \%$ petani responden tidak menggunakan pupuk kandang.

5. Penggunaan dosis pupuk berlebihan

Produksi dan kualitas tanaman akan maksimal jika menggunakan pupuk dengan jumlah yang cukup dan seimbang. Hasil wawancara menunjukkan petani yang menggunakan dosis pupuk sesuai anjuran petani responden masih rendah yaitu sebesar $90 \%$

6. Pendidikan rendah

Tingkat pendidikan petani sangat berpengaruh terhadap penerimaan teknologi yang diberikan, makin tinggi tingkat pendidikan seseorang semakin cepat dalam proses alih teknologi.

Berdasarkan hasil wawancara dengan responden dapat diketahui tingkat pendidikan petani responden masih rendah yaitu 50\% berpendidikan SD. Hal ini mengakibatkan adopsi teknologi budidaya tanaman berjalan lambat sehingga petani harus diberikan pendidikan secara terus menerus melalui penyuluhan pertanian.

Dengan pendidikan yang masih rendah tersebut, maka keterampilan anggota kelompok tani dalam pembuatan pupuk organik menjadi rendah pula.

7. Umur petani relatif tua

Umur berpengaruh terhadap kemampuan fisik petani dalam mengelola usahataninya, semakin tua umur petani maka kemampuan kerjanya relatif menurun.

Berdasarkan hasil survey, $50 \%$ umur petani responden $41-50$ tahun. Hal ini menunjukkan tingginya presentase umur petani responden tergolong tua sehingga berpengaruh terhadap penerimaan materi penyuluhan tentang teknologi budidaya tanaman, khususnya dalam pembuatan pupuk organik, selain itu kondisi fisik yang dimiliki semakin menurun. Faktor umur juga berpengaruh terhadap perubahan sikap.

8. Pemberdayaan anggota kelompok tani masih kurang 
Berdasarkan

hasil

wawancara, 60\% anggota kelompok tani belum berperan serta secara aktif dalam kegiatan kelompok tani, sehingga hanya terdapat sebagain kecil saja anggota kelompok tani yang aktif. Hal ini menyebabkan beberapa kegiatan dalam kelompok tani tidak berjalan sebagaimana seharusnya.

\section{Faktor-faktor Eksternal}

Faktor eksternal adalah faktor-faktor yang berasal dari luar lingkungan petani, terdiri dari peluang $(\mathrm{O})$ dan ancaman $(\mathrm{T})$.

\section{a. Peluang (O)}

1. Teknologi masih bisa dikembangkan

Pertanian di masa mendatang memerlukan teknologi tepat guna dan spesifik lokasi yang memperhatikan aspek keamanan produk untuk dikonsumsi dan ramah lingkungan. Teknologi yang terus dikembangkan antara lain benih unggul, pupuk organik, pengendalian hama penyakit secara terpadu dan penggunaan pestisida alami.

2. Kebijakan pemerintah mendukung ketahanan pangan

Pembangunan tidak akan terlepas dari adanya suatu kebijakan, baik kebijakan dari pemerintah daerah, provinsi, pusat dan lembaga internasional. Kebijakan yang mendukung ketahanan pangan antara lain: subsidi pupuk, sertifikasi benih, program SL-PTT (Sekolah Lapang Pengelolaan Tanaman Terpadu) yang memberikan pelatihan dan percontohan kepada petani. Program PUAP (Pengembangan Usaha Agribisnis Pedesaan) sebagai bantuan modal agar petani dapat mengembangkan usaha tani ke arah agribisnis serta PPL.

3. Pertumbuhan penduduk

Bertambahnya penduduk akan meningkatkan permintaan bahan pangan dan produk pertanian secara umum. Oleh karena itu pengembangan produk pertanian mempunyai peluang untuk terus dikembangkan.

4. Pemanfaatan lahan kering

Dari data monografi Desa Bicorong tahun 2010, lahan kering di Desa Bicorong seluas $264 \mathrm{Ha}$ belum dimanfaatkan secara optimal. Dengan teknologi yang ada, lahan kering dapat dimanfaatkan dengan penanaman komoditi bernilai ekonomis tinggi seperti tanaman palawija, ubi-ubian dan tanaman hortikultura sehingga pendapatan petani bertambah.

5. Diversifikasi pangan

Program pemerintah untuk diversifikasi pangan merupakan peluang bagi petani untuk memanfaatkan lahan pertanian secara optimal sehingga dapat menambah pendapatan petani.

b. Ancaman (T)

1. Petani tergantung pada pupuk kimia

Selama ini petani sangat tergantung pada penggunaan pupuk kimia, pendistribusian pupuk yang tidak lancar dapat menghambat proses budidaya dan berpengaruh 
terhadap produktivitas. Namun, ketergantungan terhadap pupuk kimia ini dapat menjadi ancaman karena usahatani menjadi tidak ramah lingkungan sebagaimana konsep go green yang sedang digalakkan oleh pemerintah.

2. Serangan hama dan penyakit

Serangan hama penyakit dapat menyebabkan produktivitas menurun bahkan gagal panen.

3. Perubahan cuaca dan bencana alam

Perubahan cuaca mengakibatkan musim tanam berubah. Terjadinya bencana alam (kekeringan dan banjir) banyak disebabkan oleh anomali iklim dan kerusakan Sumber Daya Alam (SDA) sehingga berakibat pada menurunnya produktivitas lahan pertanian.

4. Biaya produksi semakin meningkat

Banyak faktor produksi yang diperlukan dalam usahatani, diantaranya tenaga kerja dan sarana produksi. Setiap tahun nilai dari faktor-faktor produksi semakin meningkat. Hal ini akan mempengaruhi pengembangan usaha tani.

5. Irigasi belum lancar

Pengairan yang tidak lancar akan menjadi faktor penghambat dalam kegiatan usaha tani.
B. Alternatif

Strategi

Pengembangan SDM Petani di Desa Bicorong

Berdasarkan

hasil

identifikasi SWOT, berbagai kemungkinan alternatif strategis dibuat dengan matrik SWOT seperti pada Tabel 1. Sehingga berdasarkan matrik SWOT dapat dirumuskan strategi SWOT sebagai berikut:

\section{Strategi Kekuatan-Peluang} $(\mathbf{S}-\mathbf{O})$

Strategi S-O dibuat dengan memanfaatkan kekuatan untuk merebut dan memanfaatkan peluang yang ada. Antara lain:

a. Meningkatkan pembinaan petani melalui kelompok tani yang dilakukan secara intensif dan berkesinambungan.

Pembinaan petani

melalui kelompok tani yang dilakukan secara intensif dan berkesinambungan dapat meningkatkan SDM petani. Penyuluh pertanian akan menyampaikan informasi dan teknologi yang dibutuhkan oleh petani. Teknologi pertanian terus dikembangkan untuk membantu petani dalam berusaha tani agar produksi dan kualitas yang dihasilkan meningkat, dengan dukungan pemerintah berupa kebijakan subsidi pupuk dapat meringankan biaya produksi. Partisipasi petani dalam kelompok tani menunjukkan bahwa petani ingin menambah 
pengetahuan dan keterampilan mereka.

b. Optimalisasi lahan melalui konsep agribisnis dan berkelanjutan

Pemanfaatan lahan pertanian menggunakan teknologi spesifik lokasi dapat meningkatkan produktivitas. Dengan peningkatan SDM diharapkan petani melakukan usaha tani bukan hanya untuk kegiatan agribisnis tetapi juga menjaga kelestarian SDA agar berkelanjutan bagi generasi sekarang dan generasi yang akan datang.

c. Memanfaatkan lahan kering secara optimal

Peningkatan SDM petani akan menciptakan petani yang kreatif dan inovatif. Lahan kering yang kurang subur dengan ditunjang teknologi yang ada dapat dimanfaatkan secara optimal. Selain mendukung program diversifikasi pangan juga dapat menambah penghasilan petani.

d. Memanfaatkan kotoran hewan ternak sebagai pupuk organik

Tersedianya hewan ternak di Desa Bicorong merupakan potensi bahan baku untuk pembuatan pupuk organik. Sehingga kotoran hewan ternak tersebut dapat diolah menjadi pupuk organik baik dalam bentuk cair maupun dalam bentuk padat. e. Mengoptimalkan sumber mata air

Air sangat dibutuhkan untuk suatu budidaya, petani yang berkualitas akan mampu memanfaatkan ketersediaan air untuk mengembangkan usaha lain dengan komoditas yang bernilai ekonomis.

\section{Strategi Kelemahan - Peluang} (W-O)

Strategi W-O dibuat dengan cara meminimalkan kelemahan untuk memanfaatkan peluang yang ada antara lain:

a. Meningkatkan peranan kelompok tani agar SDM petani meningkat

Kelompok tani merupakan tempat belajar dan kerjasama para petani. Sebagai tempat belajar, pengetahuan dan keterampilan petani akan bertambah sedangkan sebagai wadah kerjasama, petani dapat mengatasi permasalahan permasalahan yang dihadapi karena keterbatasan yang dimiliki.

b. Meningkatkan kemampuan kelompok tani dalam penerapan teknologi

Selama ini petani melakukan usaha tani secara tradisional berdasarkan pengalaman. Penyuluhan pertanian yang intensif dan berkesinambungan disertai pelatihan dan percontohan akan meningkatkan pengetahuan dan perilaku petani sehingga 
mempercepat penerapan guna.

teknologi budidaya yang tepat

Tabel 1. Matrik SWOT Pengembangan SDM Petani Di Desa Bicorong

\begin{tabular}{|c|c|c|}
\hline Faktor Eksternal & $\begin{array}{l}\text { STRENGTHS (S) } \\
\text { - Ada kelompok tani } \\
\text { - Tersedianya hewan } \\
\text { ternak } \\
\text { - Ada motivasi untuk } \\
\text { berkelompok } \\
\text { - Kebijakan pemerintah } \\
\text { mendukung } \\
\text { - Ketersediaan lahan } \\
\text { masih luas } \\
\text { - Tenaga kerja cukup } \\
\text { tersedia } \\
\text { - Ada irigasi semi teknis }\end{array}$ & $\begin{array}{l}\text { WEAKNESSES (W) } \\
\text { - Penerapan teknologi } \\
\text { masih rendah } \\
\text { - Kurangnya modal } \\
\text { usaha tani } \\
\text { - Lahan usaha tani } \\
\text { sempit } \\
\text { - Produksi dan kualitas } \\
\text { masih rendah } \\
\text { - Pendidikan rendah } \\
\text { - Umur petani relatif tua } \\
\text { - Penggunaan dosis } \\
\text { pupuk berlebihan } \\
\text { - Pemberdayaan anggota } \\
\text { kelompok tani masih } \\
\text { kurang }\end{array}$ \\
\hline $\begin{array}{l}\text { OPPORTUNITIES (O) } \\
\text { - } \text { Teknologi masih bisa } \\
\text { dikembangkan } \\
\text { - Kebijakan pemerintah } \\
\text { mendukung ketahanan } \\
\text { pangan } \\
\text { - Pertumbuhan } \\
\text { penduduk } \\
\text { - Pemanfaatan lahan } \\
\text { - } \text { kering } \\
\text { - Diversifikasi pangan }\end{array}$ & $\begin{array}{l}\text { STRATEGI SO } \\
\text { - Meningkatkan } \\
\text { pembinaan petani } \\
\text { melalui kelompok tani } \\
\text { yang dilakukan secara } \\
\text { intensif dan } \\
\text { berkesinambungan } \\
\text { - Optimalisasi lahan } \\
\text { melalui konsep } \\
\text { agribisnis dan } \\
\text { berkelanjutan } \\
\text { - Memanfaatkan lahan } \\
\text { kering secara optimal } \\
\text { - Mengoptimalkan } \\
\text { sumber mata air } \\
\text { - Memanfaatkan kotoran } \\
\text { hewan ternak sebagai } \\
\text { pupuk organik }\end{array}$ & $\begin{array}{l}\text { STRATEGI WO } \\
\text { - Meningkatkan } \\
\text { kemampuan kelompok } \\
\text { tani dalam penerapan } \\
\text { teknologi } \\
\text { - Meningkatkan peranan } \\
\text { kelompok tani agar } \\
\text { SDM petani meningkat }\end{array}$ \\
\hline $\begin{array}{l}\text { THREATS (T) } \\
\text { - Disribusi pupuk tidak } \\
\text { lancar }\end{array}$ & $\begin{array}{l}\text { STRATEGI ST } \\
\text { - Pemberdayaan } \\
\text { kelompok tani untuk }\end{array}$ & $\begin{array}{l}\text { STRATEGI WT } \\
\text { - Meningkatkan } \\
\text { penerapan teknologi }\end{array}$ \\
\hline
\end{tabular}




\begin{tabular}{|l|l|l|}
\hline - Serangan hama dan & meningkatkan & dan pengembangan \\
penyakit & pemanfaatan SDA & usaha \\
- Perubahan cuaca dan & - Pengembangan usaha & - Pemberdayaan \\
bencana alam & tani melalui kegiatan & kelompok tani untuk \\
- Biaya produksi & kelompok & mengembangkan usaha \\
semakin meningkat & & pertanian \\
- Pengairan belum & & \\
lancar & & \\
\hline
\end{tabular}

3. Strategi Kekuatan - Ancaman (S - T)

Strategi S-T dibuat dengan cara menggunakan kekuatan untuk mengatasi ancaman, antara lain:

a. Pemberdayaan kelompok tani untuk meningkatkan pemanfaatan SDA

Pembinaan dan

pendampingan kelompok tani diharapkan dapat merubah perilaku (sikap) petani kearah yang lebih baik. Petani akan mengelola sumber daya yang ada untuk mendukung usaha tani misalnya: pembuatan dan penerapan pupuk organik sehingga petani tidak akan tergantung pada penggunaan pupuk kimia atau pihak swasta.

b. Pengembangan usaha tani melalui kegiatan kelompok

Usaha tani yang dilakukan secara berkelompok akan menguntungkan petani karena bisa menekan biaya produksi dan meningkatkan produktivitas misalnya dalam pengadaan sarana produksi (benih, pupuk, pestisida dan alsintan), pengaturan pola tanam komoditas yang diusahakan serta pengaturan air.

\section{StrategiKelemahan}

a. Meningkatkan penerapan teknologi dan pengembangan usaha

Melalui kelompok tani, petani akan mendapatkan informasi tentang teknologi pupuk organik. Selain digunakan sendiri, pupuk organik juga bernilai ekonomis sehingga dapat menambah penghasilan dan membuka lapangan pekerjaan.

b. Pemberdayaan kelompok tani untuk mengembangkan usaha pertanian

Kelompok tani yang mandiri akan menciptakan petani yanng berwawasan luas dan berjiwa agribisnis. Petani dapat merencanakan pola tanam dengan berbagai komoditi dan menggunakan varietas unggul. Hal ini menjadi salah satu cara untuk mencegah serangan hama dan penyakit serta menghadapi perubahan cuaca yang ekstrim.

\section{Strategi Pengembangan SDM Petani di Desa Bicorong}


Berdasarkan matrik SWOT dan analisis SWOT, diperoleh gambaran tentang strategi yang bisa digunakan untuk pengembangan SDM petani dalam pembuatan pupuk organik di Desa Bicorong.

Berdasarkan nilai total faktor-faktor internal, faktor kekuatan (S) mempunyai nilai lebih besar daripada faktor kelemahan (W) yaitu 83,89 \%. Ini menunjukkan petani di Desa Bicorong dapat meminimalkan dan menghilangkan kelemahan yang ada dengan kekuatan yang mereka miliki. Sedangkan nilai total faktor-faktor eksternal, faktor peluang (O) mempunyai nilai lebih besar daripada faktor ancaman (T) yaitu 89,53 \%, ini menunjukkan petani di Desa Bicorong dapat memanfaatkan peluang yang ada untuk menghadapi ancaman yang akan terjadi.

Strategi yang paling tepat digunakan untuk pengembangan SDM petani dalam pembuatan pupuk organik di Desa Bicorong berdasarkan analisis faktor internal dan faktor eksternal adalah strategi kekuatan - peluang $(\mathrm{S}-\mathrm{O})$, dimana kelompok tani yang menjadi kekuatan utama (97,33 \%) diharapkan mampu merubah perilaku petani agar bisa memanfaatkan kebijakan pemerintah yang menjadi peluang utama (100 $\%)$ sehingga petani mampu menggunakan teknologi pertanian yang menjadi kelemahan utama (94,67 \%) dan selalu kreatif dan inovatif dalam berusaha tani sehingga biaya produksi yang semakin meningkat tidak lagi menjadi ancaman petani $(90,67 \%)$. Strategi S-O yang bisa digunakan antara lain:

1. Meningkatkan pembinaan petani melalui kelompok tani yang dilakukan secara intensif dan berkesinambungan.

2. Optimalisasi lahan pertanian dan sumber air melalui konsep agribisnis dan berkelanjutan.

3. Optimalisasi pemanfaatan kotoran hewan ternak sebagai pupuk organik.

Pembinaan kelembagaan secara intensif dan berkesinambungan sangat diperlukan untuk meningkatkan pengetahuan dan keterampilan petani beserta keluarganya. Keberadaan kelompok tani sangat menunjang keberhasilan usaha tani karena kelompok tani berfungsi sebagai kelas belajar, unit produksi dan wahana kerjasama para petani.

Kelompok tani sebagai kelas belajar merupakan wadah bagi petani untuk berinteraksi guna meningkatkan pengetahuan, keterampilan dan sikap dalam berusaha tani agar lebih baik dan menguntungkan sehingga kesejahteraan petani beserta keluarganya tercapai. Dalam proses belajar, kelompok tani diarahkan agar mampu berhubungan dan bekerjasama dengan sumber informasi, baik yang berasal dari sesama petani, instansi maupun pihak lain. 
Kelompok tani sebagai unit produksi dapat dikembangkan menjadi kelompok usaha dengan mengelola usaha tani berwawasan agribisnis dengan model sistem pertanian terpadu. Dalam penerapan sistem pertanian terpadu, petani tidak hanya mengelola satu macam tanaman tetapi berbagai macam tanaman. Orientasi bukan lagi pada produksi komoditi tertentu tetapi pada pendapatan usaha tani. Kelompok diarahkan agar dapat memiliki kemampuan dan mengambil keputusan untuk menentukan pola usaha tani yang menguntungkan berdasarkan informasi yang tersedia dalam bidang teknologi, sosial, pemasaran, sarana produksi dan sumber daya alam serta dapat menumbuhkan pola kemitraan dengan pihak swasta dan pihak lain yang terkait dalam pelaksanaan usaha tani dengan pendekatan agribisnis.

Kelompok tani sebagai wahana kerja sama adalah memperkuat kerja sama diantara petani dalam kelompok dan antar kelompok serta dengan pihak lain untuk meningkatkan produktivitas dan pendapatan. Kelompok tani perlu membangun hubungan kelembagaan dengan kios sebagai penyedia sarana produksi dan pihak swasta untuk kepentingan usaha (modal, pemasaran) dan kesejahteraan anggota kelompok.

Pembinaan kelompok tani dapat dilakukan melalui pendekatan kemitraan dan bersifat partisipatif, dimana penyuluh atau pembina tidak merasa dirinya sebagai orang yang lebih tinggi dari petani tetapi sebagai mitra yang membantu mereka memberikan berbagai informasi teknologi, ekonomi dan sosial sehingga dengan hubungan kemitraan yang baik, rasa percaya diri petani akan semakin tinggi. Dalam pembinaan kelompok tani perlu mengetahui metode yang akan digunakan sesuai dengan kemampuan kelompok dan kekuatan usahatani serta dapat meningkatkan kemandirian kelompok tani secara partisipatif dalam rangka alih teknologi terhadap usaha tani yang berorientasi agribisnis.

\section{KESIMPULAN DAN SARAN}

\section{A. Kesimpulan}

Hasil penelitian tentang strategi pengembangan SDM petani dalam pembuatan pupuk organik di Desa Bicorong dapat disimpulkan sebagai berikut:

1. a. Faktor-faktor internal yang mempunyai tingkat kepentingan mulai dari tertinggi sampai terendah adalah: (a) Kekuatan: ada kelompok tani, tersedianya hewan ternak, ada irigasi semi teknis, ada motivasi untuk berkelompok, ketersediaan lahan masih luas, kebijakan pemerintah mendukung, tenaga kerja cukup tersedia.

Kelemahan: penerapan teknologi masih rendah, 
modal usaha tani masih kurang, produksi dan kualitas masih rendah, umur petani relatif tua, penggunaan dosis pupuk berlebihan, pendidikan masih rendah, lahan usaha tani masih sempit.

b. Faktor-faktor eksternal yang mempunyai tingkat kepentingan mulai dari tertinggi sampai terendah adalah: (a) Peluang: kebijakan pemerintah mendukung, diversifikasi pangan, pemanfaatan lahan kering, teknologi masih bisa dikembangkan, pertumbuhan penduduk. (b) Ancaman: biaya produksi semakin meningkat, serangan hama dan penyakit, distribusi pupuk kurang lancar, irigasi belum lancar, perubahan cuaca dan bencana alam.

2. Strategi yang bisa digunakan untuk mengembangkan SDM petani adalah strategi kekuatanpeluang (S-O) yaitu meningkatkan pembinaan petani melalui kelompok tani secara intensif dan berkesinambungan serta optimalisasi pemanfaatan kotoran hewan ternak sebagai pupuk organik.

\section{B. Saran}

1. Kegiatan penyuluhan pertanian akan efektif jika jumlah anggota dalam kelompok tani dibatasi 30-35 orang.

2. Memberikan peluang kepada anggota kelompok tani untuk mengikuti berbagai percontohan dan pelatihan tentang teknologi budidaya seperti pembuatan pupuk organik, agar keterampilan dan pengetahuan petani bertambah.

3. Hubungan dan kerjasama antara kelompok tani dengan instansi terkait maupun pihak swasta hendaknya lebih ditingkatkan agar kelompok tani lebih maju dan berkembang.

4. Instansi terkait memberikan pembinaan yang lebih intensif dan berkesinambungan agar kemandirian petani terwujud. 


\section{DAFTAR PUSTAKA}

Anantanyu, Sapja. 2004. Gambaran Kemiskinan Petani Dan Alternatif Pemecahannya. Makalah Falsafah Sains. Institut Pertanian Bogor.

Anonymous. 2006. Sistem Penyuluhan Pertanian, Perikanan Dan Kehutanan. Undang-Undang RI. No. 16 Tahun 2006. Presiden RI.

2007. Modul 1 - 4 Sekolah Tinggi Penyuluhan Pertanian Malang. Badan Pengembangan SDM Pertanian. Departemen Pertanian.

2007. Pedoman Pembinaan Kelembagaan Petani. Permentan. No. 273/kpts/OT.160/4/2007. Departemen Pertanian. Jakarta.

2008. Modul 1 - 4 Sekolah Tinggi Penyuluhan Pertanian Malang.

Badan Pengembangan SDM Pertanian. Departemen Pertanian.

Badan Pusat Statistik Republik Indonesia. 2009. Data Statistik 2009. BPS. Jakarta. http://www.bps.go.id

Daniel, Moehar. 2003. Metode Penelitian Sosial Ekonomi. Dilengkapi Beberapa Alat Analisa Dan Penentuan Penggunaan. PT. Bumi Aksara. Jakarta.

Setiawan, IG, Nurahimah, Yusoff, M dan Jahi, A. 2009. Menemukan MasalahMasalah Petani Untuk Dicarikan Solusinya Sebagai Upaya Menolong Meningkatkan Pengetahuan Dan Keterampilan Mereka. Institut Pertanian Bogor. www.scribd.com

Machmur, Mulyono. 2008. Agriwacana: The Power of Penyuluhan Pertanian Membangun Kemandirian Petani. Sinar Tani. Edisi 10-16 September 2008 No. 3269 Tahun XXXIX.

Rangkuti, Freddy. 2001. Analisis SWOT Teknik Membedah Kasus Bisnis. Reorientasi Konsep Perencanaan Strategis untuk Menghadapi Abad 21. PT. Gramedia Pustaka Utama. Jakarta.

Soekartawi. 1988. Prinsip Dasar Komunikasi Pertanian. Universitas Indonesia (UI: Press). Jakarta.

Supadi. 2004. Pembangunan Pertanian Dan Perekonomian Pedesaan Melalui Kemitraan Usaha Berwawasan Agribisnis. Pusat Penelitian dan Pengembangan Sosial Ekonomi Pertanian. Bogor. Pse.litbang.deptan.go.id

Suharto, Edi. 2006. Membangun Masyarakat Memberdayakan Rakyat. Kajian Strategis Pembangunan Kesejahteraan Sosial Dan Pekerjaan Sosial. PT. Ravika Aditama. Bandung.

Subejo. 2009. Sumber Daya Manusia Dan Pedesaan. Kolom: Liputan Khusus. Jakarta. www.facebook.com/topic.php.uid 



















































































































































































































































































































































